\title{
Penanaman Karakter Nasionalisme Cinta Bahasa Indonesia pada Bulan Bahasa dan Sastra
}

\author{
Intan Kusumawati \\ Pendidikan Pancasila dan Kewarganegaraan, Universitas Cokroaminoto Yogyakarta \\ J1. Perintis Kemerdekaan, Gambiran, Umbulharjo, Kota Yogyakarta 55161 \\ Email: intan.kusumawati@ucy.ac.id
}

\begin{abstract}
ABSTRAK
Tujuan penelitian ini adalah untuk mengetahui implementasi penanaman pendidikan karakter nilai nasionalisme melalui mencintai bahasa Indonesia pada bulan bahasa di Sekolah Dasar Ngoto Sewon Bantul. Karakter nasionalisme cinta bahasa Indonesia ini merupakan perwujudan cinta kepada tanah air dan bangsa melalui mencintai penggunaan bahasa Indonesia sebagai bahasa pengantar pendidikan di sekolah dan sebagai bahasa persatuan. Tujuan penanaman karakter nasionalisme ini adalah agar siswa mencintai dan dapat menggunakan bahasa Indonesia dengan baik dan benar sebagai bahasa nasional dan bahasa yang bisa menyatukan persatuan dan kesatuan dalam kehidupan siswa pada keseharian di keluarga, sekolah dan masyarakat. Pada bulan Oktober diperingati bangsa Indonesia sebagai bulan bahasa dan sastra, yang merupakan wujud cinta tanah air serta merujuk pada sejarah bangsa dan negara Indonesia. Sekolah Dasar Ngoto Sewon Bantul sebagai sekolah krida budaya berbasis hak anak menyelenggarakan serangkaian kegiatan berupa lomba-lomba untuk memperingati bulan bahasa dan sastra tersebut. Kegiatan implementasi penanaman pendidikan karakter nilai nasionalisme diselenggarakan beberapa macam kegiatan berupa lomba-lomba seperti menyimak cerita, menulis cerita pendek, membaca puisi, cipta pantun, menulis puisi, mendongeng, menyanyi, pidato, mewarnai dan membuat poster. Tujuan kegiatan bulan bahasa dan sastra ini adalah agar siswa mempunyai karakter mencintai bahasa dan sastra yang merupakan nilai-nilai luhur bangsa Indonesia yang perlu dijaga serta tetap dilestarikan.
\end{abstract}

Kata Kunci: Penanaman karakter nasionalisme; cinta tanah air; bahasa dan sastra.

\begin{abstract}
The purpose of this study was to determine the implementation of the cultivation of character education in the value of nationalism through loving Indonesian in the language month at Ngoto Sewon Bantul Elementary School. The nationalism character of Indonesian love is a manifestation of love for the motherland and nation through loving the use of Indonesian as the language of instruction in education in schools and as the language of unity. The purpose of inculcating the character of nationalism is that students love and can use Indonesian properly and correctly as a national language and language that can unite unity and unity in the daily lives of students in the family, school and community. In October the Indonesian nation is celebrated as a month of language and literature, which is a form of love for the motherland and refers to the history of the Indonesian nation and state. Ngoto Sewon Bantul Elementary School as a child rights-based cultural krida school held a series of activities in the form of competitions to commemorate the language and literary month. The implementation activities of the inculcation of character education in the value of nationalism were held several kinds of activities in the form of competitions such as listening to stories, writing short stories, reading poetry, creating poetry, writing poetry, storytelling, singing, speeches, coloring and making posters. The purpose of this language and literary month activity is that students have the character to love language and literature which are the noble values of the Indonesian people that need to be preserved and remain preserved.
\end{abstract}

Keywords: Cultivating the character of nationalism; love the motherland; language and literature. 


\section{PENDAHULUAN}

Tantangan dengan berkembangnya teknologi serta pesatnya arus modernisasi yang masuk ke Indonesia menjadi salah satu permasalahan yang menimpa negeri kita tercinta Indonesia. Negeri Indonesia yang kaya akan sumber daya manusia ini jika tidak dikelola dengan baik dan bijak akan menjadi masalah tersendiri. Banyak tenaga kerja Indonesia yang memilih bekerja di negara tetangga karena negara tersebut bisa menjanjikan hasil keuangan yang cukup besar. Nilai nasionalisme untuk menggunakan produk dalam negeri juga sudah mulai luntur karena maraknya pasar bebas produk luar negeri yang kualitas baik namun harga murah, menjadikan tantangan tersendiri terhadap produk dalam negeri. Bahasa juga menjadi tantangan tersendiri, ketika tuntutan warga Negara Indonesia juga mesti mempelajari bahasa asing seperti bahasa Inggris dan Mandirin.

Bahasa Indonesia adalah bahasa nasional yang bila diucapkan tidak benar dan salah akan menjadi tidak baik. Penanaman nasionalisme cinta tanah air perlu ditanamkan sejak dini agar terwujud rasa nasionalisme cinta Indonesia. Bahasa adalah alat komunikasi bagi umat manusia dan kekayaan yang mahal harganya. Penggunaan bahasa yang baik dan benar sangatlah diperlukan agar bisa menjadi identitas bangsa yang beradab. Penggunaan gaya bahasa yang kasar dan tidak sopan akan menganggu nilai nilai karakter yang baik. Kesopan dalam berbicara dan bertutur katapun mesti dilestarikan dan perlu ditanamkan sejak dini. Bahasa menunjukan budaya dan norma yang berlaku dalam suatu negara yang beradab. Https://koranindonesia.id/bahasa-indonesia-dalam-revolusi-4-o/diunduh pada hari Kamis, 8 November 2018.

Dalam penggunaan bahasa Indonesia yang baik dan benar tentunya perlu adanya kesinambungan dan tujuan daripada makna bahasa itu sendiri. Dalam sekolahpun siswa dituntut menggunakan bahasa yang baik, benar dan sopan. Siswa mampu berbicara secara efektif dan efisien (2008) untuk mengungkapkan gagasan, pendapat, kritikan, perasaan, dalam berbagai bentuk kepada berbagai mitra bicara sesuai dengan tujuan dan konteks pembicaraan. Dalam bertuturkatapun perlu ditanamkan agar menghasilkan tutur kata yang benar, baik dan sesuai dengan norma dan budaya bangsa kita. Bahasa Indonesia menurut Hyun, P. J. (2015) adalah sebagai alat komunikasipun mulai berkembang, dipakai oleh beberapa orang baik dari bangsa kita atau bangsa lain dan banyak digunakan oleh penutur asing merupakan tantangan tersendiri bagi bangsa Indonesia untuk menyikapinya tantangan ini semua. Peluang dan tantangan dalam Murti, S. (2016) terhadap bahasa Indonesia semakin besar pula yang dihadapinya. Berbagai 
peluang bahasa Indonesia dalam era globalisasi seperti saat ini antara lain adanya dukungan luas dari berbagai pihak, termasuk peran media massa.

Globalisasi menurut Lan, T. J., \& Manan, M. (2011) tidak seharusnya dilihat sebagai ancaman atau tantangan semata, melainkan baik perbedaan dan keanekaragaman etnik, budaya, dan juga bahasa daerah menjadi satu bangunan bersama yang bernama "Negara-Bangsa Indonesia". Apabila tantangan ini tidak bisa dijawab oleh bangsa kita maka kita akan kehilangan bahasa nasional kita bahasa Indonesia. Saat ini menurut Susanto (2016) keberadaan bahasa Indonesia mendapat tantangan yang serius baik itu tantangan internal maupun tantangan eksternal. Bahasa Indonesia yang seharusnya harus terus dilestarikan keberadaannya sekarang ini cenderung mengalami pergeseran. Penanaman karakter menurut Kusumawati, I. (2017) mesti ditanamkan sejak dini dan dilakukan pembiasaan. Oleh karena itu tantangan bagi bangsa dan negara Indonesia, tugas kita untuk tetap melestarikan budaya dan bahasa Indonesia ditengah-tengah arus modern yang berkembang pesat sekarang ini. Serta bagaimana pelaksanaan penanaman karakter nasionalisme cinta bahasa Indonesia bisa ditanamkan ke peserta didik dan siswa sejak dini.

\section{METODE PENELITIAN}

Dalam penelitian ini peneliti menggunakan metode deskriptif. Menurut Nazir (1998: 63) metode deskriptif merupakan metode yang digunakan dalam meneliti sekelompok manusia, suatu pemikiran dan peristiwa pada masa sekarang. Tujuan metode ini menjelaskan kondisi dan peristiwa yang dialami lewat pengalaman dan gambaran situasi dan kondisi yang terjadi serta mengungkapkan kejadian dan fakta yang dialami. Metode deskriptif untuk menggambarkan dan menganalisa kejadian yang terjadi. Subyek penelitian ini adalah siswa, guru, kepala perpustakaan serta kepala sekolah SD Ngoto Sewon Bantul. Penelitian ini dilakukan pada Sekolah Dasar Ngoto di Jalan Imogiri Barat Km 5, Semail, kecamatan Sewon kabupaten Bantul.

\section{HASIL DAN PEMBAHASAN}

\section{Penanaman karakter nasionalisme cinta bahasa Indonesia}

Penanaman karakter yang diselenggarakan SD Ngoto bulan November melaksanakan bulan bahasa yang mana kegiatan tersebut untuk memperingati bulan bahasa dan sastra yang jatuh pada bulan Oktober. Di mana bertepatan dengan dengan hari Sumpah Pemuda yang menyatakan bahwa bangsa Indonesia menyatakan satu nusa, satu bangsa dan $\underline{\text { satu bahasa yaitu Indonesia. Penanaman karakter nasionalisme agar siswa mencintai dan }}$ 
bangsa terhadap bangsa dan negaranya. Dalam kegiatan tersebut ada beberapa perlombaan yang diperlombakan. Penanaman karakter nasionalisme ini melalui penyelenggaraan lomba-lomba dalam memperingati bulan bahasa dan sastra tersebut diselenggarakan agar meningkatkan rasa nasionalisme siswa cinta tanah air melalui cinta bahasa Indonesia sebagai bahasa nasional dan bahasa persatuan. Sesuai dengan hasil wawancara kepada Kepala Sekolah SD Ngoto yaitu Bapak Suparyanto, S.Pd pada kegiatan bulan bahasa dan sastra pada Rabu tanggal 7 November 2018, sebagai berikut:

"Kegiatan tersebut dapat memperkuat literasi sekolah bagi siswa dan memperkokoh penguatan pendidikan karakter siswa SD Ngoto. Penyelenggarakan dilakukan oleh panitia dan terbagi menjadi beberapa cabang lomba yang terdiri dari menyimak, bercerita, menulis cerpen, cipta pantun, menulis puisi, mendongeng, menyanyi, pidato, mewarnai dan membuat poster. Sehingga beraneka macam lomba tersebut akan menambah wawasan siswa dalam rangka untuk kegiatan literasi. Kegiatan tersebut akan membekali siswa karena beberapa cabang yang diperlombakan juga oleh dinas pendidikan terkait akan dilombakan kejenjang lebih tinggi lagi."

Adapun kegiatan yang diselenggarakan dalam memperingati bulan bahasa dan sastra dalam rangka penanaman karakter nasionalisme sebagai berikut:

\section{Menyimak Cerita}

Menyimak cerita adalah merupakan ketrampilan menyimak sebuah cerita. Kegiatan ini tentunya tidak lepas dari kegiatan mendengarkan, membaca dan menulis. Perlu konsentrasi dalam menyimak cerita dan memahami betul isi dari pada cerita tersebut kemudian baru dibuat rangkuman atau kesimpulan dari menyimak cerita tersebut. Dengan menyimak cerita rakyat, cerita kepahlawanan dan cerita keindahan dan kekayaan bumi Indonesia maka siswa dalam menyimak cerita diharapkan dapat memupuk rasa cinta terhadap tanah air.

Dengan menyimak cerita rakyat bisa mengambil hikmat dari cerita tersebut dan mengetahui dari mana cerita itu dibuat tentunya ada cerita sekitar cerita rakyat yang berada di seluruh nusantara yang bisa menambah wawasan pengetahuan tentang suku bangsa dan wilayah nusantara. Dengan menyimak cerita tentang pahlawan siswa diharapkan bisa mengetahui perjaungan pahlawan dan bisa menjadi suri tauladan perjuangan para pahlawan. Dengan menyimak cerita kekayaan bumi nusantara akan mengetahui bahwa wilayah Indonesia subur makmur dan menghasilkan sumber daya alam yang bisa digunakan untuk mencukupi kebutuhan rakyat dan masyarakat Indonesia tentunya. Melalui kegiatan menyimak cerita tertanam rasa nasionalisme cinta tanah air Indonesia kita tercinta. 
Sesuai dengan hasil wawancara kepada Bapak Ismono, S.Pd. sebagai guru dan dewan juri pada kegiatan bulan bahasa dan sastra pada Rabu tanggal 7 November 2018, sebagai berikut:

“Dengan kegiatan menyimak akan membiasakan siswa untuk mendengarkan cerita, serta melatih mendengarkan cerita. Kegiatan menyimak cerita yang diselenggarakan pada lomba adalah memperingati bulan bahasa dan sastra ini menggali potensi anak atau siswa agar dapat diketahui sejak dini dan bisa dikembangkan di kelak kemudian hari."

Hal senada juga disampaikan pada wawancara kepada Rondiyati Fajriyah sebagai guru dan dewan juri pada kegiatan bulan bahasa dan sastra pada Rabu tanggal 7 November 2018, sebagai berikut:

"Dengan kegiatan menyimak siswa lebih mencintai bahasa Indonesia dan menambah ketrampilan menyimak cerita. Kegiatan menyimak ini dapat dijadikan ajang untuk mempersatukan siswa baik di sekolah ataupun kegiatan di masyarakat."

\section{Menulis Cerita Pendek}

Menulis cerita pendek adalah ketrampilan yang dilakukan dengan cara menuliskan ide dan pemikiran yang hendak dituangkan penulis. Penulis akan menuangkan ide membuat kerangka isi cerita dan mulai menulisnya. Ketrampilan menulis ini juga tidak lepas dengan ketrampilan membacanya. Lewat menulis maka bisa menyalurkan ide, pendapat dan pemikiran ataupun pengalaman yang dirasakan dan mempunyai tujuan ataupun makna dibalik cerita pendek tersebut. Ketika seseorang menulis cerpen tentang negerinya maka pembaca akan bisa memaknai apa isi cerita dari cerita pendek tersebut. Dengan membaca cerpen tentang sejarah Indonesia, perjuangan Indonesia, Harapan Indonesia akan menambah rasa cinta tanah air dan jiwa nasionalismenya.

Sesuai dengan hasil wawancara kepada Maryanti, S.Pd. sebagai guru dan dewan juri pada kegiatan bulan bahasa dan sastra pada Rabu tanggal 7 November 2018, sebagai berikut:

"Bahasa Indonesia adalah sebagai bahasa persatuan dengan lomba-lomba yang diselenggarakan pada bulan bahasa dan sastra ini dapat meningkatkan kreativitas siswa, dengan adanya perlombaan juga melatih bersaing secara sehat dan sportif. Kegiatan ini dapat mempererat pertemanan diantara siswa-siswa di SD Ngoto untuk memperkuat rasa persatuan dan kesatuan bangsa serta wujud nasionalisme."

Sama halnya dengan hasil wawancara kepada Iva Rahmawati sebagai kepala perpustakaan "Ceria" Sekolah Dasar Ngoto pada kegiatan bulan bahasa dan sastra pada Rabu tanggal 7 November 2018, sebagai berikut:

"Lomba yang diselenggarakan ini merupakan usaha untuk mendukung gerakan literasi yang sudah lama dicanangkan di SD Ngoto. Lewat kegiatan menulis pendek atau yang sering disebut dengan membuat cerpen maka siswa dilatih untuk 
mengasilkan karya melalui tulisan sesuai dengan imajinasi dan pengalaman yang dialami siswa. Sebelum membuat cerpen tentunya siswa sudah banyak membaca cerpen yang ada di berbagai buku bacaan baik yang ada di buku pelajaran atau buku-buku fiksi ataupun non fiksi yang terdapat di perpustakaan atau di pojok baca yang ada di sekitar sekolah dan juga buku yang dibaca siswa di tempat lain."

\section{Membaca Puisi}

Membaca puisi adalah ketrampilan berbicara di depan umum dan mengungkapkan serta mengekresikan isi dari bacaan puisi tersebut. Dalam membaca puisi, siswa akan dilatih rasa kepercayaan dirinya. Dengan membaca puisi tentang perjuangan dan tentang bangsa Indonesia akan memumpuk cinta nasionalisme. Dengan membaca puisi dapat mengekspresikan diri dan rasa yang dialami. Membaca puisi menjadikan semangat pembaca dan pendengarnya. Dengan membaca puisi siswa akan bisa membawa suasana bahagia gembira dan semangat untuk mencintai tanah airnya dan juga bangsanya.

Sesuai dengan hasil wawancara kepada Ibu Syoimah, S.Pd. sebagai guru dan dewan juri pada kegiatan bulan bahasa dan sastra pada Rabu tanggal 7 November 2018, sebagai berikut:

" Kegiatan membaca puisi ini untuk meningkatkan bacaan siswa dalam membaca puisi serta mengekpresikan isi dari puisi tersebut, kegiatan ini untuk meningkatkan rasa percaya diri siswa untuk berekspresi. Dengan kegiatan ini siswa dilatih untuk percaya diri dan mandiri dalam berlatih. Ketika teman yang lain membaca puisi teman yang lain mendengarkan dan memperhatikan otomatis kegiatan ini ada usaha untuk saling menghargai dan menjadi kegiatan ini menambah wawasan dan cinta tanah air."

\section{Cipta Pantun}

Cipta pantun adalah ketrampilan untuk menuangkan ide, gagasan serta maksud dan tujuan daripada pantun tersebut. Cipta pantun adalah karya sastra yang indah dan merupakan karya terdahulu yang dibuat mempunyai tujuan dan penuh makna dibalik pembuatan pantun tersebut. Ada pesan dan amanat yang akan dituangkan dalam membuat pantun tersebut. Pencipta pantun perlu banyak membaca dan banyak belajar untuk membuat pantun yang penuh dengan irama dalam membuatnya agar indah dan baik untuk dibaca dan dibacakan.

Sesuai dengan hasil wawancara kepada Herlina Dwi Novitasari, S.Pd. sebagai guru dan dewan juri pada kegiatan bulan bahasa dan sastra pada Rabu tanggal 7 November 2018, sebagai berikut:

"Anak-anak menjadi lebih memahami bahwa bahasa Indonesia menjadi bahasa persatuan dan bahasa keseharian serta siswa menjadi lebih mencintai bahasa Indonesia yang merupakan bahasa persatuan." 


\section{Menulis Puisi}

Menulis sebuah puisi merupakan ketrampilan menulis yang tentunya di dalam puisi tersebut mempunyai makna dan tujuan dalam pembuatannya. Ketrampilan menulis puisi ini akan dapat dilatih ketika penulis banyak membaca contoh puisi lama ataupun kontemporer agar memiliki wawasan yang luas dalam mengekspresikan isi puisi lewat kata demi kata penuh makna. Ketrampilan menulis puisi ini juga dapat dipakai sebagai penyalur ide dan pendapat penulis untuk mengungkapkan rasa yang dialami dan dirasakannya. Sesuai dengan hasil wawancara kepada Sri Wahyuni, S.Pd. sebagai guru dan dewan juri pada kegiatan bulan bahasa dan sastra pada Rabu tanggal 7 November 2018, sebagai berikut:

"Dengan kegiatan menulis puisi siswa menjadi bisa melatih ketrampilan menulis dan berani menyampaikan ide dan karyanya dengan penuh percaya diri. Lewat menulis puisi menggunakan bahasa Indonesia, siswa akan mencintai bahasa Indonesia sebagai bahasa persatuan dan kesatuan. Lewat kegiatan lomba-lomba pada bulan bahasa dan sastra ini siswa menjadi lebih bangga dan mencintai tanah air Indonesia."

\section{Mendongeng}

Mendogeng adalah ketrampilan membaca dan berekspresi untuk menyampaikan makna dan arti dongeng yang hendak didongengkan. Ketrampilan ini juga perlu dilatih agar terbiasa menceritakan dengan ekspresi yang bisa ditangkap maksud dan makna dongeng tersebut. Dalam mendongeng diperlukan kepercayaan diri dan mencintai isi dari dongeng tersebut serta dapat menyampaikan nasehat ataupun makna dibalik dongeng yang dibacakan. Lewat dongeng juga bisa mencetak dan menanamkan nilai-nilai karakter bangsa. Penyampaian pembacaan dongeng juga memiliki ketrampilan tinggi agar makna dongeng itu tersampaikan kepada para pendengar. Kegiatan mendongengpun bisa dilaksanakan di mana saja, kapan saja dan kepada siapa saja. Ketrampilan mendongeng yang bagus perlu latihan dan kerja keras agar bisa membuat pendengar tertanam makna di balik cerita dongeng tersebut.

Sesuai dengan hasil wawancara kepada Murtini, S.Pd. sebagai guru dan dewan juri pada kegiatan bulan bahasa dan sastra pada Rabu tanggal 7 November 2018, sebagai berikut:

"Mendongeng adalah kegiatan seni bercerita yang dilakukan seseorang agar supaya orang lain yang mendengarkan bisa mengerti isi dari cerita dongeng tersebut serta bisa memaknainya. Dengan mendongeng dengan menggunakan bahasa Indonesia tentunya siswa akan bangga dan menghargai penggunaan bahasa Indonesia sebagai bahasa keseharian yang bisa dimengerti."

\section{Menyanyi}

Menyanyi akan ketrampilan berbicara lewat nada dan irama. Ketrampilan menyanyi akan menghasilkan sikap disiplin yang tinggi karena perlu banyak latihan agar makna dan suara baik 
intonasi dan pengahyatan dalam bernyanyi adalah tepat sasaran. Perlu adanya penjiwaan dalam menyanyikan sebuah lagu. Adanya penanaman karakter dibalik sebuah nyanyian. Penjiwaan dan acting juga sangat diperlukan dalam menyanyi ini. Dengan menyanyi bisa mencintai Negara dan bangsa. Lewat lagu lagu nasional, cinta tanah air dan lagu semangat dan perjuangan akan memumpuk rasa nasionalisme yang tinggi terhadap mencintai tanah air Indonesia ini.

Sesuai dengan hasil wawancara kepada Listiana Ambarsari, S.Pd.sebagai guru dan dewan juri pada kegiatan bulan bahasa dan sastra pada Rabu tanggal 7 November 2018, sebagai berikut:

"Dengan bernyanyi siswa bisa menyalurkan bakat dan jiwa seninya. Bernyanyi dengan intonasi yang tepat dan penghayatan yang baik serta vokal yang jelas akan membuat kepercayaan diri siswa. Melatih kedisiplinan dan penjiwaan siswa dalah bernyanyi. Dengan bernyanyi dengan bahasa Indonesia yang baik dan benar

\section{Pidato} menunjukkan sikap cinta tanah air dan bangsanya."

Pidato adalah ketrampilan berbicara di depan banyak orang untuk menyampaikan ide, gagasan dan tujuan dari pada isi pidato tersebut. Seseorang yang akan berpidato tentunya menyiapkan naskah terlebih dahulu, menyiapkan draf dan mulai menulis ide serta apa tujuan yang akan disampaikan dalam pidatonya. Ketrampilan berpidato juga akan melatih kedisiplinan dan kepercayaan diri siswa di depan banyak orang.

Sesuai dengan hasil wawancara kepada Siti Juwariyah, S.Pd. I sebagai guru dan dewan juri pada kegiatan bulan bahasa dan sastra pada Rabu tanggal 7 November 2018, sebagai berikut:

"Berpidato akan menambah rasa percaya diri siswa. Sebelum berpidato siswa menentuka tema dan merancang tulisan ide apa yang mau disampaikannya dalam berpidato nanti. Dengan menulis rancangan pidato dengan menggunakan bahasa Indonesia yang sesuai dengan kaidah penulisan siswa akan mudah untuk mempelajari isi pidato tersebut dan bisa menyampaikan ide dan gagasan ketika berpidato. Kegiatan ini menunjukkan rasa cinta tanah air."

Senada dengan hasil wawancara kepada Naya Maharani Putri siswa kelas VI B sebagai peserta lomba membuat pidato pada kegiatan bulan bahasa dan sastra pada Rabu tanggal 7 November 2018, sebagai berikut:

"Kegiatan lomba pidato menjadikan siswa percaya diri dan berharap bisa melaksanakan lomba pidato ini dijadikan sebagai ajang menyalurkan bakat dan juga penyaluran pendapat serta berlatih berbicara di depan umum. Kegiatan ini bisa menjadikan siswa menjadi yang terbaik dalam berpidato dengan menggunakan bahasa Indonesia yang baik dan benar."

\section{Mewarnai}

Mewarnai adalah ketrampilan untuk menuangkan kreasi menorehkan warna ke $\underline{\text { dalam hasil karya atas gambar agar menghasilkan gambar yang indah dan sesuai dengan }}$ 
komposisinya. Keberanian dalam mengambil keputusan untuk memilih warna dan ketepatan dalam memadukan warna adalah suatu ketrampilan yang perlu dilatih. Dengan mewarnai gambar sesuai dengan tema bulan bahasa dan sastra diharapkan siswa bisa memaknai dan mencintai kebudayaan dan cinta terhadap tanah air, bangsa dan Negara Indonesia.

Sesuai dengan hasil wawancara kepada Budiyono, S.Pd. sebagai guru dan dewan juri pada kegiatan bulan bahasa dan sastra pada Rabu tanggal 7 November 2018, sebagai berikut:

"Kegiatan mewarnai yang diselenggarakan pada bulan bahasa dan sastra ini menjadikan siswa berani mengekspresikan diri dalam mewarnai gambar sesuai tema lomba. Anak sangat senang dan semangat dalam mengikiuti lomba tersebut. Kegiatan ini bisa mengali bakat dan minat siswa. Anak diberi kebebasan untuk menuangkan ekspresinya ke dalam hasil karyanya, sesuai dengan semboyan SD ngoto yaitu sekolah krida budaya berbasis hak anak."

Sesuai dengan hasil wawancara kepada Rafa Putra Ardiyansyah siswa kelas II sebagai peserta lomba membuat poster pada kegiatan bulan bahasa dan sastra pada Rabu tanggal 7 November 2018, sebagai berikut:

"Kegiatan lomba ini menjadikan saya dan teman-teman merasakan senang dan gembira bisa mengikuti lomaba-lomba dalam bulan bahasa dan sastra di SD Ngoto Sewon Bantul berharap hasil lomba ini bisa menang namun yang terpenting kegiatan ini menjadi akrab dan menyatukan persahabatan dan pertemanan dengan

\section{Membuat Poster} lomba dan saling menghargai hasil karya temannya."

Membuat poster adalah ketrampilan menunagkan ide dan gagasan ke dalam goresan di kertas dengan menambah komposisi warna yang sesuai akan menambah hidup poster dan maksud dari pada pembuatan poster tersebut. Poster tentang bulan bahasa akan menambah rasa cinta kepada tanah air. Poster yang baik adalah poster yang ketika orang lain melihat, membaca dan menikmati isi poster tadi bisa tersampaikan ide, tujuan dan gagasan darpada poster tersebut. Poster tentang bahasa Indonesia sebagai bahasa nasional dan bahasa persatuan akan menambah rasa cinta kepada bangsa dan negara Indonesia.

Sesuai dengan hasil wawancara kepada Laily dan Zulfa siswa kelas VI sebagai peserta lomba membuat poster pada kegiatan bulan bahasa dan sastra pada Rabu tanggal 7 November 2018, sebagai berikut:

"Kegiatan membuat poster ini sebagai ajang berkompetensi sehat dan berharap bisa menang, kegiatan ini bisa mengembangkan bakat dan berharap lebih baik lagi ke depannya dalam membuat poster dan berusaha menjadi yang terbaik." 
Hal yang sama dikemukakan Umi Alfi Nur Khasanah, S.Pd. sebagai guru dan dewan juri pada kegiatan bulan bahasa dan sastra pada Rabu tanggal 7 November 2018, sebagai berikut:

"Dengan kegiatan membuat poster ini melatih siswa untuk berkarya dan menghasilkan karya seni, kegiatan ini juga menjadikan siswa percaya diri dan saling bisa menghargai hasil karya buatan teman-temannya. Membuat poster menjadikan siswa disiplin menggunakan waktunya dan cermat membuat karyanya dan berkreasi mewarnainya dengan semangat dan senang membuatnya membuat hasil karya yang nantinya akan bisa dinikmati orang lain yang melihatnya dan di poster tersebut bisa menyampaikan ide lewat poster tersebut untuk tetap mencintai bahasa Indonesia dan menggunakan bahasa Indonesia sebagai bahasa persatuan"

\section{KESIMPULAN}

Penanaman nilai-nilai karakter memang sebaiknya dari sejak dini. Pendidikan Sekolah Dasar bisa menjadi rujukan penanaman karakter nasionalisme setelah mereka dapatkan penanamana karakter di rumah. Sekolah memfasilitasi peserta didik atau menjadikan sekolah sebagai tempat di mana siswa bisa melalukan pembiasaan dan penanaman karakter nasionalisme mulai dari kehadiran di sekolah sampai siswa melaksanakan kegiatan di sekolahan dan sampai pulang kembali ke rumah. Melalui bulan bahasa dan sastra yang diperingati dengan bermacam lomba literasi di dalamnya menambah pengetahuan dan ketrampilan siswa serta menanamkan karakter nasionalisme cinta bangsa dan Negara tercinta Indonesia.

\section{SARAN}

Penelitian tentang penanaman karakter nasionalisme ini semestinya menjadi rujukan bagi penelitian selanjutnya. Lewat bahasa Indonesia nilai-nilai karakter nasionalisme bisa ditanamkan sejak dini untuk mengetahui sejarah bangsa dan harapan dan nilai-nilai luhur bangsa Indonesia. Penanaman karakter sejak dini akan mendasari peserta didik agar ke depan menjadi pribadinya mandiri, kerja keras, disiplin, memiliki ketrampilan, tegas, dan berkarakter bangsa.

\section{DAFTAR PUSTAKA}

Https://koranindonesia.id/bahasa-indonesia-dalam-revolusi-4-o/diunduh pada hari Kamis, 8 November 2018, pukul 19.00 WIB.

Hyun, P. J. (2015). Potensi dan tantangan bahasa Indonesia menuju bahasa internasional. Artikel. Jurusan Bahasa Melayu-Indonesia, Hankuk University of Foreign Studies, Korea Selatan, hal, 12-20. 
Kusumawati, I. (2017). Pengembangan Karakter Siswa Raudlatul Athfal Berbasis Pendidikan Agama Islam. a - ibyān: Jurnal Pendidikan Anak Usia Dini, 1(02), 139148.

Lan, T. J., \& Manan, M. A. (Eds.). (2011). Nasionalisme dan Ketahanan Budaya di Indonesia: Sebuah Tantangan. Yayasan Pustaka Obor Indonesia.

Moh. Nazir. (1998). Metode Penelitian. Jakarta. Ghalia Indonesia.

Murti, S. (2016). Eksistensi Penggunaan Bahasa Indonesia di Era Globalisasi.

Nasional, U. (2008). Bahasa Indonesia. Jakarta: Pusat Bahasa Departemen Pendidikan Nasional.

Susanto, H. (2016). Membangun budaya literasi dalam pembelajaran bahasa Indonesia menghadapi era mea.JP-BSI (Jurnal Pendidikan Bahasa dan Sastra Indonesia), 1(1), 12-16. 